\title{
Future Aquaculture Trends of Sivas in the Central Anatolia of Turkey
}

\author{
Seher Dirican \\ Department of Fisheries, Suşehri Timur Karabal Vocational Training School, Cumhuriyet University Sivas, \\ Turkey
}

*Corresponding Author: Seher Dirican, Department of Fisheries, Suşehri Timur Karabal Vocational Training School, Cumhuriyet University Sivas, Turkey

\begin{abstract}
On a global scale aquaculture is a rapidly growing sector. Sivas has quite a rich inland water potential in terms of aquaculture, but there is surprisingly no compiled information about planned future aquaculture developments of Sivas in the Central Anatolia of Turkey. Similarly, there are no forecasts indicating a development of aquaculture in Sivas over the next 10 years. This study describes the future aquaculture trends of Sivas in the Central Anatolia of Turkey. Current data of aquaculture production of Sivas Provincial Directorate of Food, Agriculture and Livestock of 2001-2014 were used for this purpose. Future of aquaculture production trends were analyzed. Over the past 14 years, aquaculture production increased from 319.50 tons in 2001 to 5554.50 tons in 2014. A trend model, fitted to the 2001-2014 aquaculture production, estimated 10554.25 tons for 2025 in Sivas. If the present trend continues, the aquaculture production of Sivas will double by 2025.
\end{abstract}

Keywords: Aquaculture, Future, Trends, Sivas, Turkey.

\section{INTRODUCTION}

Global aquaculture production has continued to grow in the new millennium, albeit more slowly than in the 1980s and 1990s. In the course of half a century or so, aquaculture has expanded from being almost negligible to fully comparable with capture production in terms of feeding people in the world. Aquaculture has also evolved in terms of technological innovation and adaptation to meet changing requirements. World aquaculture production attained another all-time high in 2010, at 60 million tons. In the last three decades (1980-2010), world food fish production of aquaculture has expanded by almost 12 times, at an average annual rate of $8.8 \%$. Aquaculture enjoyed high average annual growth rates of $10.8 \%$ and $9.5 \%$ in the $1980 \mathrm{~s}$ and $1990 \mathrm{~s}$, respectively, but has since slowed to an annual average of $6.3 \%$ [1]. The most marine cultured species are sea bass (Dicentrarchus labrax), sea bream (Sparus aurata) and bluefin tuna (Thunnus thynnus) and, while inland aquaculture is mostly based on an intensive farming of rainbow trout (Oncorhynchus mykiss) in Turkey. At present, Turkey is the 5th largest aquaculture producer and the 3rd largest finfish aquaculture producer in Europe. It is also the 2nd largest producer in Europe of sea bass and sea bream (after Greece) and rainbow trout (after Norway). Rainbow trout ranks the first $(44.72 \%)$ followed by seabass $(29.79 \%)$, and seabream $(22.07 \%)$ in Turkey [2].

Commercial rainbow trout farming started in Turkey in 1971 and it has increased dramatically afterwards. In 1986, 990 tons of rainbow trout was produced in Turkey [3]. The production level reached 122873 tons according to the data in 2013 [4]. In Sivas aquaculture has developed rapidly in recent years. It was recorded as 770 tons in 2007, the level of aquaculture production in Sivas has already reached at 5124.5 tons in 2010. Accordingly, aquaculture production in Sivas a very rapid growth rate of approximately $665 \%$ was found in 3 years. Suşehri this produced only $83.5 \%$ of total Sivas production with 4278 tons of aquaculture production in 2010 [5]. Sivas has quite a rich inland water potential in terms of aquaculture, but there is no compiled information about planned future developments of aquaculture in Sivas. Similarly, there are no forecasts indicating a development of aquaculture in Sivas over the next 10 years. This study describes the future aquaculture trends of Sivas in the Central Anatolia of Turkey. 


\section{Materials AND Methods}

\subsection{Study Area}

The study area is Sivas which is situated in $39^{\circ} 31^{\prime} 11^{\prime \prime} \mathrm{N} ; 37^{\circ} 17^{\prime} 42$ "E in the eastern part of the Central Anatolian region of Turkey. Sivas is located in rural areas. Sivas has a population of 627056. Sivas province is divided into 17 districts. Average height of Sivas province is 1275 meters from sea level. There is not the sea coast of Sivas. Sivas has quite rich inland waters resources with 7 major rivers (Kızılırmak River, Yeşilırmak River, Çaltı Stream, Kelkit Stream, Tohma Stream, Yıldız Stream, Hurman Stream), 9 lakes (Tödürge Lake, Hafik Lake, Lota-1 Lake, Lota-2 Lake, Seyfe Lake, Kuru Lake, Karagöl Lake, Ulaş Lake, Gökpınar Lake) and 13 artificial water bodies from dams (Çamlıöze Dam, Gazibey Dam, Gölova Dam, Güneykaya Dam, 4 Eylül Dam, İmranlı Dam, Kanak Dam, Kılıçkaya Dam, Maksutlu Dam, Mursal Dam, Karacalar Dam, Pusat-Özen Dam, Yapıaltın Dam). The total length of $972 \mathrm{~km}$ of rivers and tributaries pass from within the boundaries of the province of Sivas. Also, nine natural lakes and thirteen dam lakes are present in Sivas and their a total area covered of their is about 2588.5 ha [6-8].

\subsection{Data Analysis}

The data, used in the study were obtained from Sivas Provincial Directorate of Food, Agriculture and Livestock 2001-2014. According to these data, amount of aquaculture production were determined as tons/year 319.5 in 2001, 309.00 in 2002, 281.00 in 2003, 282.00 in 2004, 270.00 in 2005, 228.03 in 2006, 368.4 in 2007, 486.58 in 2008, 1071.35 in 2009, 2767.96 in 2010, 5089.50 in 2011, 5577.50 in 2012, 5544.00 in 2013 and 5544.50 in 2014. These data represented amount of aquaculture production in Sivas, they have been analyzed according to both time and space in this paper. Statistical model of the relationship between amount of aquaculture production and year variables and the correlation equation depends on the estimated trend showing her course and multivariate linear regression analysis was revealed. In the direction of this model, the estimations of amount of aquaculture production until 2025 were made for Sivas in the Central Anatolia of Turkey. SPSS for windows version 17.5 statistical software was used for all data analysis.

\section{RESUltS}

Sivas is in a lucky situation to have so many water resources for aquaculture. Trends in the aquaculture are studied in Sivas. Aquaculture in Sivas is mainly related to inland water aquaculture, which shows the best expansion prospects. The aquaculture sector can be characterized by mainly one species, rainbow trout (Oncorhynchus mykiss Walbaum, 1792) in Sivas. Development aquaculture trends in Sivas from 2001 to 2025 can be seen in Figure 1. Over the past 14 years, aquaculture production increased from 319.50 tons in 2001 to 5554.50 tons in 2014 in Sivas. A trend model, fitted to the 2001-2014 aquaculture production, estimated 5672.95 tons for 2015, 6161.08 tons for 2016, 6649.21 tons for $2017,7137.34$ tons for $2018,7625.47$ tons for $2019,8113.60$ tons for $2020,8601.73$ tons for 2021, 9089.86 tons for 2022, 9577.99 tons for 2023, 10066.12 tons for 2024, 10554.25 tons for 2025 in Sivas (Figure 1). The trend model implies linear growth at 488.13 tons per year. These statistics for the next 10 years show continued positive growth in Sivas aquaculture production. At least in the medium term, it would appear that the more intensive, aquaculture will continue to occupy a useful role in overall production in Sivas. The inland water aquaculture mainly focuses on local market and the scale of the culture is relatively stable in Sivas. Especially in recent years, aquaculture has become a fast growing sector in Sivas. Thus aquaculture in Sivas has very good prospects looking into the future.

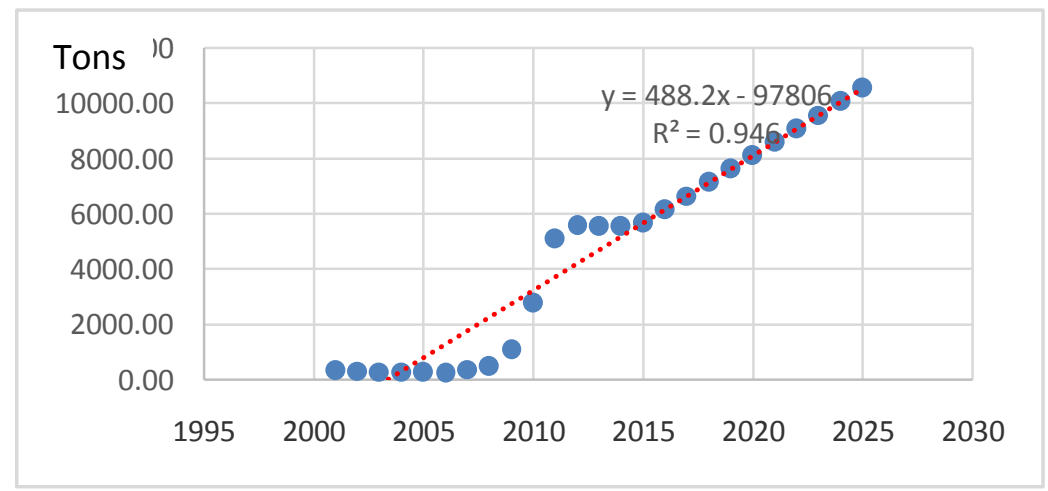

Figure 1. Development aquaculture trends in Sivas from 2001 to 2025. 
According to the data, amount of aquaculture annual change rate were determined as $-3.29 \%$ in 2002 , $-9.06 \%$ in $2003,0.36 \%$ in $2004,0.36 \%$ in $2004,-4.26 \%$ in $2005,-15.54 \%$ in $2006,61.56 \%$ in 2007 , $32.08 \%$ in $2008,120.18 \%$ in $2009,158.36 \%$ in $2010,83.87 \%$ in $2011,9.59 \%$ in 2012 and $-0.60 \%$ in 2013 and $0.19 \%$ in 2014. The aquaculture sector in Sivas is witnessing rapid growth with rainbow trout. Despite that aquaculture of Sivas has grown very fast since last 14 years, this expansion was mainly based on expansion of culture area and production capacity. The amount of aquaculture annual change rate ranged from $-15.54 \%$ to $158.36 \%$ between 2001 and 2014 in Sivas. A trend model, fitted to the 2001-2014 amount of aquaculture annual change rate, estimated $2.13 \%$ for $2015,8.60 \%$ for $2016,7.92 \%$ for $2017,7.34 \%$ for $2018,6.84 \%$ for $2019,6.40 \%$ for $2020,6.02 \%$ for $2021,5.67 \%$ for 2022, $5.37 \%$ for $2023,5.10 \%$ for $2024,4.85 \%$ for 2025 in Sivas. According to the trend model, the amount of aquaculture annual change rate ranged from $2.13 \%$ to $8.60 \%$ in Sivas. Sivas production of aquaculture has estimated at an mean annual change growth proportion of $6.02 \%$ for the next decade. The current trends indicate that investment in the sector was being recorded in Sivas Nevertheless, the growth of aquaculture was perceived to be relatively fast. Aquaculture in Sivas has a bright future and will continue to see rapid growth. Increases in fish demand in the coming decades are projected to be largely met by growth of aquaculture in Sivas.

\section{DISCUSSION}

World aquaculture production continues to grow, albeit at a slowing rate. According to the latest available statistics collected globally by FAO, world aquaculture production attained another all time high of 90.4 million tons in 2012, including 66.6 million tons of food fish and 23.8 million tons of aquatic algae. World food fish aquaculture production expanded at an average annual rate of $6.2 \%$ in the period 2000-2012, more slowly than in the periods 1980-1990 (10.8\%) and 1990-2000 (9.5\%). World food fish aquaculture production expanded at an average annual rate of $6.2 \%$ in the period 2000-2012 from 32.4 million to 66.6 million tons [9]. Hall et al. [10] estimated that aquaculture production will grow from 60 million tons in 2010 to 100 million tons by 2030. Sayg1 et al. [11] the total probable cultivation estimation value of Turkey was found as 284337 tons for 2030. The probable estimation value of Turkey was determined for the rainbow trout is 126272 tons for 2030 [11].

There have been considerable changes in the structure of aquaculture in Sivas, which becomes evident through analysis of amount of aquaculture production as demonstrated in Figure 1. Sivas aquaculture sector is broadly categorized into inland water aquaculture. Inland water aquaculture has recorded significant progress over the last decade. The Sivas aquaculture sector has seen rapid growth for decades until recently. The dominant aquaculture systems in Sivas include the land based in concrete pools and dams in cages distributed across the province. The aquaculture production has increased dramatically with the growing number in Sivas, since 2001. It also has rapid improvement acceleration. The contribution of aquaculture production has increased sharply from 1071.35 ton in 2009 to 5089.50 ton in 2011. Aquaculture were produced from 47 companies with an overall production of 5544.50 tons in 2014. According to the aquaculture production figures in the last 14 years the production by aquaculture has increased approximately by 17 times recorded. The most important factor in this increase was the initiation of the use of dams for Sivas's aquaculture. Despite this increase, the sector possesses scope for further increases in aquaculture production by way of horizontal expansion and higher productivity per unit area. In Sivas, aquaculture production has moved from being a highly traditional activity to being a well developed sector. With a rich inland water potential in terms of aquaculture, investments in the sector are trending upwards. Appropriate technologies, financial investments, and entrepreneurial enthusiasm primarily account for this situation. In addition, aquaculture has been practiced mostly in the central, Suşehri District, and Gürün District and Gemerek District [5].

About $80 \%$ of Sivas's total aquaculture production occurs in Suşehri district from Çamligöze Dam Lake in cage farms [8]. In particularly, aquaculture in dams is very popular in Sivas. The rainbow trout is enclosed in a cage that allows free water exchange. The location of the cage in the water body may be critical for proper water circulation. Although very good information is available on cage culture in Sivas, it may be an overlooked asset in the aquaculture sector. As cage intensive culture in Çamlıgöze Dam Lake has begun in 2008. The intensive aquaculture occupies a distinct position in Sivas aquaculture sector. In next years the use of new dams and reservoirs will take effect and aquaculture production will be further increased. For this and many more reasons, the outlook for aquaculture of Sivas in the future is bright. The rapid growth in aquaculture seems set to continue in 
the near term in Sivas. According to development trend of Sivas's aquaculture production, the annual production is expected to reach 10554.25 tons by the year 2025. As noted here, the aquaculture sector dams the most lucrative opportunities and should be given special focus. Other aquaculture systems, such as integrated fish farming and cage culture, are under appreciated assets for present and future development of sustainable aquaculture in Sivas.

\section{Conclusions}

Aquaculture is a very important sector in Sivas's agricultural development. The sector has grown rapidly in terms of culture area and production in recent years. In Sivas, the rapid growth in aquaculture seems set to continue in the near term. Indicators pointing to good growth potential include increasing demand for rainbow trout, emergence of aquaculture as a sector for investment, and recognition of its potential for expansion in Sivas. This study provides new information on the future aquaculture trends of Sivas in the Central Anatolia of Turkey. To the best of our knowledge, the forecasts indicating a development of aquaculture over the next 10 years in Sivas for the first time. Sivas's aquaculture has grown dramatically in the past few years and has apparently entered an exponential growth phase. A trend model, fitted to the 2001-2014 aquaculture production, estimated 10554.25 tons for 2025 in Sivas. If the present trend continues, Sivas's aquaculture production will double by 2025 . Forecasts indicate the demand for the aquaculture production of Sivas will continue to increase strongly over the next decade, and thus make a prominent contribution to providing the global population with quality protein. Finally, the trend model shows, beside a user friendly applicability, a good performance and prediction accuracy which offers opportunities for further use. The future of aquaculture in Sivas appears bright and rapid expansion is expected to continue. Aquaculture in Sivas will continue to move an important part in global supply of fish in the future. Therefore, aquaculture in Sivas should be carefully monitored.

\section{REFERENCES}

[1] FAO (2012). World review of fisheries and aquaculture. FAO Fisheries and Aquaculture Department, Rome, Italy, pp 209.

[2] Harlığlu, A.G. (2011). Present status of fisheries in Turkey. Reviews in Fish Biology and Fisheries, 21, 667-680.

[3] Yıldız, M., Doğan, K., Bayır, A. (2011). A study on profitability of rainbow trout (Oncorhynchus mykiss) farms in Marmara Region, Turkey. Journal of Fisheries Sciences.com, 3, 172-179.

[4] Anonymous (2015). Fishery statistics. Republic of Turkey Ministry of Food, Agriculture and Livestock, General Directorate of Fisheries and Aquaculture, May 2015, Ankara, Turkey, pp 11.

[5] Dirican, S. (2013). Aquaculture situation in Sivas, Harran Üniversitesi Ziraat Fakültesi Dergisi, 17(2), 914.

[6] Dirican, S., Musul, H., Çilek, S. (2008). Potential and evaluation of aquaculture in the Sivas (Turkey) province. Journal of Fisheries Sciences.com, 2(3), 510-515.

[7] Anonymous (2011). Sivas province environmental status report. Provincial Directorate of Environment and Urbanization, Sivas, Turkey, pp 537.

[8] Dirican, S. (2014). A Study on comparison of aquaculture and capture fisheries in Sivas on Central Anatolia of Turkey. Research Journal of Environmental Science, 8(8), 451-456.

[9] FAO (2014). The state of world fisheries and aquaculture. Opportunities and challenges. Food and Agriculture Organization of the United Nations, Rome, Italy, pp 223.

[10] Hall, S.J., Delaporte, A., Phillips, M.J., Beveridge, M., O'Keefe, M. (2011). Blue frontiers: Managing the environmental costs of aquaculture. The World Fish Center, Penang, Malaysia, pp 92.

[11] Sayg1, H., Kop, A., Bayhan, B. (2011). The forecast of the future production amounts of the some fish species being cultivated in Turkey. Kafkas Üniversitesi Veteriner Fakültesi Dergisi, 17(1), 13-20.

Citation: Seher Dirican," Future Aquaculture Trends of Sivas in the Central Anatolia of Turkey", International Journal of Innovative Studies in Aquatic Biology and Fisheries (IJISABF), vol. 3, no. 2, p. 4, 2017. http://dx.doi.org/10.20431/2454-7670.0302001

Copyright: (๑) 2017 Authors. This is an open-access article distributed under the terms of the Creative Commons Attribution License, which permits unrestricted use, distribution, and reproduction in any medium, provided the original author and source are credited. 